\title{
A Multivariate Analysis of the Cranial Measurements of the Ryukyu Islanders (Males)
}

\author{
Akira TAGAYA and Jiro IKEDA \\ Laboratory of Physical Anthropology, Kyoto University
}

\begin{abstract}
The cranial measurements of the Ryukyu Islanders (males) were examined by multivariate analysis. There is a clear separation between the Okinawa and Amami districts among the Ryukyu populations. As a result of a comparison among 8 populations in the Ryukyu Islands and Honshu-Kyushu, it is clear that the Ryukyu Islanders are a local group of the Japanese people. Comparison among the Ryukyu people, Honshu-Kyushu Japanese and their surrounding populations clarified that the populations closest to the Ryukyu people are the Honshu-Kyushu Japanese followed by some of the southern people and that the population closest to the Ainu is the Ryukyu Islanders among the populations compared here. The Ryukyu people are almost equally close to the modern, proto-historic and prehistoric Japanese and the Ainu, and are comparatively far from Korean.
\end{abstract}

Since BAELZ ('11) drew attention to the significance of physical anthropological studies on Ryukyu Islanders with reference to the racial affinities of the Japanese population, there have been a number of publications concerning the physical traits of these islanders, based upon data of somatometry, dermatography, serology, etc., while little information on the human skeletal remains of the prehistoric period has been brought to light. Reports which deal with a relatively large number of modern crania are regionally restricted to the Amami district, the northern part of the Ryukyu Islands, and craniological studies on islanders of the Okinawa district, that is the southern part of the Ryukyu Islands, were found on small samples with the exception of Okinawa Honto (Hsï '48). They are as follows: Yonaguni (ADACHI 1895, KANASEKI '63,
Nagai and Sano '66) and Okinawa Honto (Kintaka '29, Hsü'48).

Recently, one of the authors obtained craniometrical data of modern crania from Nagabaka in Miyako Island, the Okinawa district, and compared them with those of modern populations in the adjacent area, using relative deviations and mean relative deviations of each population from Nagabaka (IKEDA '74). In this paper, the cranial measurements of the Ryukyu Islanders including some new data from Miyako, Iriomote, Okinawa Honto, Tokunoshima and Kikai, are examined by multivariate analysis to clarify the mutual relationships among the populations of the surrounding districts and the prehistoric and protohistoric Japanese populations. These relationships do not seem to have been examined in any previous report. 


\section{MATERIALS AND METHOD}

The adult crania without mandibles from the following islands were measured: Miyako-1 (Nagabaka; 85 males, 48 females, 2 sex unknown), Miyako-2 (Karimata; 16 males, 14 females), Iriomote (Haimi; 36 males, 23 females), Okinawa Honto-2 (Tokuchi, Unten and Tamagusuku; 11 males, 10 females), Tokunoshima -2 (Honkawa Cave ; 24 males, 29 females), Kikai (Akaren, Onozu, Oasado, Shiomichi and Keraji; 7 males, 2 females). The data of the last were used only for calculation of within-group matrix but not for comparison with other populations. The crania from both Miyako and Iriomote were examined at the cemeteries, and the others, which were collected by MIYAKE and others, at the Laboratory of Physical Anthropology, Kyoto University. The materials from Nagabaka and Karimata are probably of approximately the same period, and the age of the former was estimated not to be more than 200 years (IKEDA '74). The skulls from Haimi are judged by documentary evidence to be of people living during the period from 1734 to 1920 . Most of the materials from the other islands are presumed to belong to recent times, though the precise chronological dates are unknown. Thus, all the materials are regarded as a modern cranial series of the Ryukyu Islanders. Only the measurements of males are used for comparison in this study.

Comparative data were obtained from the following modern populations, the maximumnumber of samples among the measurements and the name of the researchers being enclosed in parentheses. The Ryukyu Islanders : Okinawa Honto-1 (48, Hsü '48), Yoron (38, Oyama '56), Tokunoshima-1 (57, Iw aI '59), Yoro (25, KIKUCHI '59) and Kikai (17, Nakano '58). Populations of areas adjacint to the Ryukyu Islanders : Northern Kyushu (108, HARADA '54), Central Kyushu (67, Matsumoto '67), Kinki (30, Miчамото '24), Kanto (144, Morita '50), Hokuriku (30, OTsuKi, '30), Tohoku (65, YAMAZAKI et al. '67), Yakumo Ainu (52, Watanabe '38), Central Korea (178, Shima '34), Fushun (77, Shima '33), Hainan (193, HuAng '48), Fukien (154, Asai '42), Seil Peipo (56, Yuang '60), Atayal (74, Chang '49), Tagalog (31, BoNin '31), Dayak (55, Bonin '31). Prehistoric and protohistoric crania, which are used for comparison, are as follows: Jomon crania, Yoshigo (57 KInTAKA '28); Yayoi crania, Doigahama (55, KANASEKI et al. '60); Kofun crania, Western Japan (31, Jo '38).

Multiple discriminant analysis is used for comparison among the populations. For interpretation of the nature of each discriminant function, discriminant loadings, or the within-group correlations between the function and the measurements, are used. Mahalanobis' D-squares are also calculated to express the whole information carried by the full set of the functions.

Within-group variance-covariance matrix was calculated for each of five groups; Ryukyu (67 samples), Kinki (27), Sakhalin Ainu (16), Tagalog (15), Dayak (27). Sakhalin Ainu (HiraI '27) was not in 
cluded in the populations compared. As a result of chi-square test, difference of matrices between Ryukyu and Kinki is not significant at $5 \%$ level, but that of matrices among Ryukyu, Kinki and Dayak is strikingly significant even at $1 \%$ level. Since there are no marked differences among the correlation matrices of these five groups, however, the mean of five matrices weighted by the sample sizes is used as the common within-group matrix. Among-group matrix is calculated from the mean of each measurement, regardless of sample sizes of the populations. Some of the data used in this analysis are not of individual samples but the mean values for the populations, however, and no statistical technique is as yet available for testing the significance of among-group differences or eigen values.

The same data were re-examined by three different techniques; the Q-mode correlation coefficient, the shape distance of Penrose and the multiple discriminant analysis on the Q-mode standardized data (Corruccini '73). Since all these results are highly consistent with those obtained by multiple discriminant analysis on the unmodified data, only the results obtained by the latter analysis will be discussed in the next section.

\section{RESULTS AND DISCUSSION}

1. Comparison among Ryukyu populations

FUNCTIONS AND LOADINGS (Fig. 1, Table 1)

The first four functions account for about $82 \%$ of the variation among 10 populations in the Ryukyu Islands.

Function 1: The difference between the Okinawa and Amami districts is clearly

Table 1. Discriminant loadings. Comparison among the Ryukyu populations.

\begin{tabular}{lcccc}
\hline Function & 1 & 2 & 3 & 4 \\
Cumultive trace (\%) & 40.3 & 63.6 & 74.1 & 82.3 \\
\hline 1. Max. cranial ln. & .036 & -.164 & .440 & -.000 \\
2. Cranial base ln. & .159 & -.029 & .108 & -.072 \\
3. Max. cranial br. & -.182 & .137 & .126 & -.446 \\
4. Min. frontal br. & .141 & -.386 & .189 & .018 \\
5. Basion-bregma ht. & .145 & -.159 & -.125 & .216 \\
6. Horizontal circ. & .202 & .020 & .436 & -.055 \\
7. Transverse arc & -.208 & -.093 & .277 & .065 \\
8. Sag. frontal arc & -.059 & -.080 & .083 & -.041 \\
9. Sag. parietal arc & -.018 & -.100 & .366 & .069 \\
10. Sag. occipital arc & -.083 & -.090 & .110 & .117 \\
11. Facial ln. & -.088 & .106 & .246 & -.339 \\
12. Bizygomatic br. & .239 & .050 & .345 & .051 \\
13. Upper facial ht. & .145 & -.244 & .425 & -.090 \\
14. Orbital br. & -.144 & -.563 & .039 & .181 \\
15. Orbital ht. & .009 & -.118 & -.011 & .088 \\
16. Nasal br. & .044 & .110 & .459 & -.267 \\
17. Nasal ht. & -.052 & .129 & .410 & .267 \\
\hline
\end{tabular}




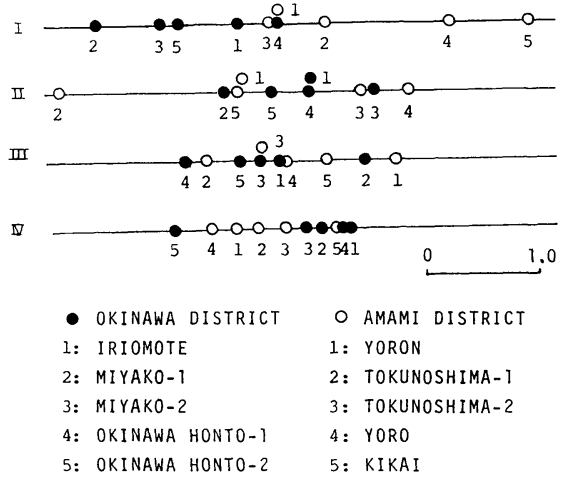

Fig. 1. Plot of the Ryukyu populations on the first four functions.

recognizable. As the arrangement of the populations on this function is generally in accordance with the geographical distribution of the populations excepting both Iriomote and Tokunoshima-2, this function might well reflect the regional differences of cranial traits in the Ryukyu Islands. There are no striking differences of loadings among the measurements, but horizontal circumference, transverse arc and bizygomatic breadth have a little higher loadings than the others.

Functions 2 and 3 : About $34 \%$ of intergroup variation is carried by these two functions; there seems, however, to be no clearly discernible overall tendency. Loa- dings are notably high in a breadth component of the frontal part (orbital breadth, minimum frontal breadth, with the negative sign) for function 2 , and in a general size component (maximum cranial length, horizontal circumference, sagittal parietal arc, bizygomatic breadth, upper facial height, nasal breadth and height, with the positive sign) for function 3 .

Function 4: On this function, it is possible to discriminate between the Okinaw a and Amami districts though not so clearly as in the case of function 1 . Combination of these two functions completely separates both districts. Maximum cranial breadth and facial length have high loadings.

\section{D-SQUARES (Table 2)}

Values among 7 populations consisting of Tokunoshima-2 and Yoron of the Amami district as well as the whole Okinawa district, excepting Miyako-1 v.s. Okinawa Honto-1 (6.86), are below 5.60. On the other hand, D-squares between each of these seven and the remaining three populations of the Amami district, with the exception of Tokunoshima-2 v.s. Yoro (3.77), are all above 5.90. Tokuno-

Table 2. D-squares among the Ryukyu populations.

\begin{tabular}{|c|c|c|c|c|c|c|c|c|c|}
\hline & $\begin{array}{c}\text { Miyako } \\
-1\end{array}$ & $\begin{array}{c}\text { Miyako } \\
-2\end{array}$ & $\begin{array}{l}\text { Okinawa } \\
\text { Honto-2 }\end{array}$ & Iriomote & $\begin{array}{l}\text { Tokuno- } \\
\text { shima-2 }\end{array}$ & $\begin{array}{l}\text { Okinawa } \\
\text { Honto-1 }\end{array}$ & Yoron & $\begin{array}{l}\text { Tokuno- } \\
\text { shima-1 }\end{array}$ & Yoro \\
\hline Miyako-2 & 4.81 & & & & & & & & \\
\hline Okinawa Honto- 2 & 24.03 & 3.77 & & & & & & & \\
\hline Iriomote & 3.75 & 2.31 & 3.73 & & & & & & \\
\hline Tokunoshima-2 & 5.56 & 2.73 & 3. 44 & 1.42 & & & & & \\
\hline Okinawa Honto- 1 & 16.86 & 4.09 & 4. 19 & 3. 52 & 2.75 & & & & \\
\hline Yoron & 5.03 & 5.00 & 4.43 & 4.22 & 3.93 & 5.18 & & & \\
\hline Tokunoshima-1 & 9.02 & 10.30 & 6.83 & 6.60 & 7.95 & 7.26 & 6.48 & & \\
\hline Yoro & 13.68 & 8.19 & 8.25 & 5.94 & 3.77 & 6.53 & 6.63 & 11. 27 & \\
\hline Kikai & 14.88 & 12.99 & 12.04 & 7.93 & 7.74 & 7.60 & 6.97 & 7.89 & 4.74 \\
\hline
\end{tabular}


shima-2 and Yoron are quite close to most of the rest, while Kikai is far from all but Yoron. Values for each pair of the populations in the same islands (Miyako, Okinawa-Honto, Tokunoshima) are not always smaller than those for other pairs.

IKEDA ('74) pointed out that there is no significant separation between the Okinawa and Amami districts, on the grounds that the difference between Miyako-1 and Okinawa Honto-1 are greater than those between Miyako-1 and Iriomote or Yoron, while the differences between Okinawa Honto- 1 and the populations of Amami district are greater than those between Okinawa Honto-1 and Miyako-1 or Iriomote. Multivariate analysis in this paper, however, shows clear discrimination between the Okinawa and Amami districts, though some of $\mathrm{D}$-squares are not in accordance with this result.

Seven populations, including all of the Okinawa district, and Tokunoshima-2 and Yoro, are close to each other, but the remaining three, Tokunoshima-1, Yoro and Kikai, are distant from all populations of the Okinawa district, particularly from both populations of Miyako. Each of these three seems to be craniometrically isolated, although Tokunoshima-2 and Yoro are relatively close.

According to anthropometrical studies published to date, the inhabitants of the Kunigami region in Okinawa Hon to come close to those of Hateruma, the seashore region of Kikai and Amami Oshima, but are different from those of Yoron and the average of Okinawa Honto (Toyama '59). On the other hand, in Okinawa Honto, the people of the northern region are similar to those of Tokunoshima (OYADOMARI '68, Tomizawa '69), and that of the central region to both of them (SAKIHARA '68), but the people of the southern region are different from other two regions (ARAGaKI '68). AoKI ('59) stated that Miyako islanders have the closest relationship to those of Yonaguni, followed by those of Amami Oshima and other Ryukyu islanders, and that the further north the populations under comparison are off from Miyako, for example, from Yakushima to Tanegashima through $\mathrm{Ku}$ chinoshima, the more different they are from the Miyako islanders. On the other hand, OMORI et al. ('66) suggested that Miyako anthropometrically resembles Ishigaki, and that both islands have a closer relationship to Tanegashima and Tokunoshima than to Okinawa Honto. Recently, Naito ('73) stated that the differences among the inhabithants of the Nansei Islands are not significantly marked and that Miyako alone is distant from all the others.

Relationships among the Ryukyu Islanders are not shown very clearly as a result of multiple discriminant analysis of modern crania, but this seems to be reasonable enough, consideing the small samples within each population and confusing effects, such as a genetic drift, which can be caused by such small samples. The findings of this study partially coincide with those of the anthropometrical comparison mentioned above. For example, the inhabitants of Okinawa Honto, particularly the northern and central 
regions, come close to those of Tokunoshima and are quite different from all the others except Yoro. It may be given as a conclusion, however, that the most sharp distinction recognizable is between the Okinawa and Amami districts mainly on function 1 .

2. Comparison among Ryukyu, Honshu and Kyushu populations.

Considering the clear discrimination between the Okinawa and Amami districts, the populations in each district were grouped together and compared with 6 populations in Honshu and Kyushu. Measurements for both of Ryukyu populations were represented by the means of measurements, unweighted by sample sizes, for five populations from each district. FUNCTIONS AND LOADINGS (Fig. 2, Table 3)

The first two functions explain about $64 \%$ of variation among 8 populations.

Function 1: This function separates the group of Kinki, Northern and Central Kyushu from the group of Amami, Okinawa, Kanto, Hokuriku and Tohoku. Central Kyushu and Tohoku are located on both extremes and far from the rest of each group. Loadings are relatively high in a general height component (ba-

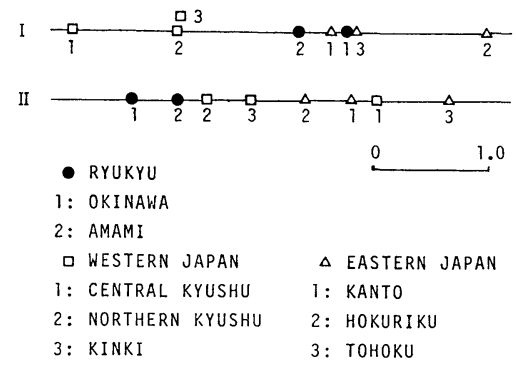

Fig. 2. Plot of the Ryukyu, Kyushu and Honshu populations on the first two functions.
Table 3. Discriminant loadingc. Comparison among the populations in Ryukyu, Kyushu and Honshu.

\begin{tabular}{lrr}
\hline \multicolumn{1}{c}{ Function } & 1 & \multicolumn{1}{c}{2} \\
Cumultive trace (\%) & 38.1 & 64.5 \\
\hline 1. Max. cranial ln. & .145 & -.077 \\
2. Ba-na ln. & -.080 & -.085 \\
3. Max. cranial br. & .024 & -.100 \\
4. Min. frontal br. & -.019 & .012 \\
5. Basion-bregma ht. & -.265 & -.110 \\
6. Horizontal circ. & .013 & .070 \\
7. Transverse arc & .019 & .176 \\
8. Frontal arc & -.121 & .033 \\
9. Parietal arc & -.146 & -.141 \\
10. Occipital arc & -.035 & .084 \\
11. Facial ln. & .036 & -.273 \\
12. Bizygomatic br. & .048 & -.180 \\
13. Upper facial ht. & -.281 & .145 \\
14. Orbital br. & .035 & -.329 \\
15. Orbital ht. & .016 & .235 \\
16. Nasal br. & -.204 & -.176 \\
17. Nasal ht. & -.105 & .130 \\
\hline
\end{tabular}

sion-bregma height, upper facial height, with the negative sign).

Function 2: Arrangement of populations on this function coincides with their geographical distribution from the south to the north in Japan, with only Central Kyushu not according with this distribution. The Amami and Okinawa districts are strikingly discriminated from Kanto and Tohoku, and such separation is not perceptible on function 1. Facial measurements, particularly those of orbit, (facial length, orbital breadth with the negative sign and orbital height with the positive sign) have relatively high loadings. Discordance of the sign among three measurements seems to reflect a close relationship between this function and facial, especially orbital, shape. 
Table 4. D-squares among the populatios in Ryukyu, Kyushu and Honshu.

\begin{tabular}{lccccccc}
\hline & Okinawa & Amami & $\begin{array}{l}\text { North } \\
\text { Kyushu }\end{array}$ & Kinki & $\begin{array}{c}\text { Central } \\
\text { Kyushu }\end{array}$ & Kanto & Hokuriku \\
\hline Amami & 2.78 & & & & & & \\
North Kyushu & 5.29 & 4.68 & & & & & \\
Kinki & 5.40 & 4.69 & 2.72 & & & & \\
Central Kyushu & 11.38 & 8.01 & 5.18 & 4.21 & & & \\
Kanto & 6.03 & 6.42 & 5.63 & 2.94 & 7.30 & & \\
Hokuriku & 7.00 & 6.88 & 9.40 & 8.96 & 14.33 & 3.81 & \\
Tohoku & 8.57 & 7.36 & 9.41 & 8.73 & 8.51 & 5.02 & 7.24 \\
\hline
\end{tabular}

\section{D-SQUARES (Table 4)}

Pairs of the populations which have relatively low $\mathrm{D}$-squares are Northern Kyushu v.s. Kinki (2.72), Okinawa v.s. Amami (2.78), Kinki v.s. Kanto (3.81). Central Kyushu and Tohoku are quite distant from the others, D-squares being for the former 7.30-14.33 exclucing 4.21 (v.s. Kinki) and 5.18 (v.s. Northern Kyushu), and for the latter 7.24-8.57, excepting 5.02 (v.s. Kanto). Consequently, it would be reasonable to divide 8 populations into three clusters; Ryukyu Islands (Amami, Okinawa), Western Japan (Northern and Central Kyushu, Kinki) and Eastern Japan (Kanto, Hokuriku, Tohoku). This clustering is parallel to the geographical division and distances among the three clusters are approximately equal as shown in Table 6 .

There is general agreement on the idea that anthropometrical data for the Ryukyu Islanders fall within the range of variation of the Honshu-Kyushu people, and KANASEKI ('55) concluded that the inhabitants of the Nansei Islands somatometrically resemble those of Southern Kyushu and differ from those of Northern Kyushu. IKeDA ('74) also presumed that Miyako and Okinawa Honto should be a local group of the Japanese population but was not able to choose the population closest to them amongst the Honshu-Kyushu people, since there is no significant difference among their mean relative deviations. The results in this study also indicate that Amami and Okinawa should be regarded as a local group of the Japanese population, but do not seem to distinguish any of Honshu-Kyushu people as the closest to the Ryukyu Islanders though D-squares show a slight tendency indicating, perhaps, that Northern Kyushu and Kinki come close to both Okinawa and Amami. Discussion of the discrepancy between this result and KANASEKI's suggestion must be left here, because data pertaining to Southern Kyushu are not included in this analysis. Judging from the loadings of function 2, on which all populations occupy their positions in a pattern similar to that on a geographic map, the features characteristic to the Ryukyu crania seem to be found in the facial part and this has already been mentioned by many authors.

3. Comparison among three Japanese clusters and their surrounding populations. FUNCTIONS AND LOADINGS (Fig. 3, Table 5) 


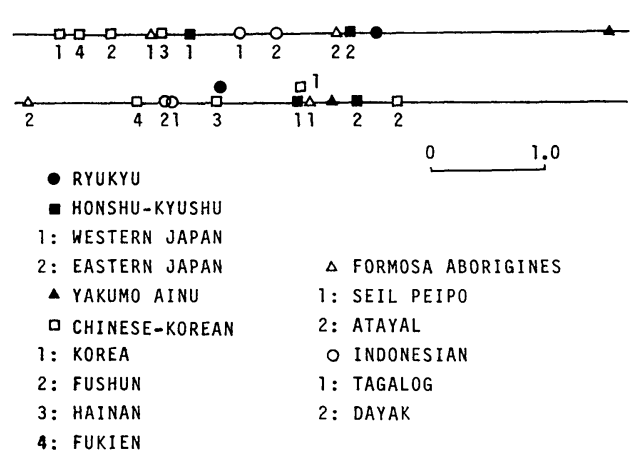

Fig. 3. Plot of the Japanese clusters and their surrounding populations on the first two functions.

Table 5. Discriminant loadings. Comparison among Japanese clusters and their surrounding populations.

\begin{tabular}{lrr}
\hline \multicolumn{1}{c}{ Function } & 1 & 2 \\
Cumultive trace (\%) & 39.1 & 57.4 \\
\hline 1. Max. cranial ln. & .268 & .222 \\
2. Ba-na ln. & .184 & .298 \\
3. Max. cranial br. & -.008 & .250 \\
4. Min. frontal br. & .232 & -.003 \\
5. Basion-bregma ht. & -.208 & .191 \\
6. Horizontal circ. & .172 & .437 \\
7. Transverse arc & -.069 & .388 \\
8. Frontal arc & .015 & .002 \\
9. Parietal arc & -.115 & -.004 \\
10. Occipital arc & -.031 & .210 \\
11. Facial ln. & .389 & .268 \\
12. Bizygomatic br. & -.023 & .197 \\
13. Upper facial ht. & -.307 & .473 \\
14. Orbital br. & .161 & .347 \\
15. Orbital ht. & -.031 & .295 \\
16. Nasal br. & .042 & -.180 \\
17. Nasal ht. & -.257 & .310 \\
\hline
\end{tabular}

The first two functions account for only $57.4 \%$ and four functions more than $80 \%$ of variation among 12 populatons. It seems, however, that only the first two are worth special mention.

Function 1: On this function, Yakumo Ainu is located at one end and Korea at the other. The Chinese populations oc- cupy positions near Korea, and the Japanese and the Indonesian, including Taga$\log$ and Dayak, occupy an intermediate position between both ends. Western Japan is located near the Chinese-Korean side, and Ryukyu and Eastern Japan near the Ainu side, but Yakumo Ainu stands apart from any other population. Three components which have relatively high loadings can be recognized; a general length component (maximum cranial length, cranial base length, horizontal circumference, facial length, with the positive sign), a general height component (basion bregma height, upper facial hegiht, nasal height, with the negative sign) and a breadth component in the frontal region (minimum frontal breadth, orbital breadth, with the positive sign).

Function 2: This locates Fushun at one end and Atayal at the other. Generally speaking, discrimination between the northern and southern populations in East Asia is discernible on this function. Loadings are relatively high in a general size component (maximum cranial length, horizontal circumference, transverse arc, cranial base length, upper facial height, orbital height, nasal height, orbital breadth, facial length, with the positive sign).

\section{D-SQUARES (Table 6)}

D-squares display a rather complicated picture of inter-populational relationships, but a relatively conspicuous contrast is discernible between Yakumo Ainu and Chinese-Korean populations, as already shown on Function 1. Values of D-squares for mutual combinations among the group 
Table 6. D-squares among Japanese clusters and their surrounding populations.

\begin{tabular}{|c|c|c|c|c|c|c|c|c|c|c|c|}
\hline & Ryukyu & $\begin{array}{l}\text { West. } \\
\text { Japan }\end{array}$ & $\begin{array}{l}\text { East. } \\
\text { Japan }\end{array}$ & $\begin{array}{l}\text { Yakumo } \\
\text { Ainu }\end{array}$ & Korea & Fushun & Hainan & Fukien & $\begin{array}{l}\text { Seil } \\
\text { Peipo }\end{array}$ & Atayal & $\begin{array}{l}\text { Taga- } \\
\log \end{array}$ \\
\hline West. Japan & 4. 53 & & & & & & & & & & \\
\hline East. Japan & 4.56 & 5.23 & & & & & & & & & \\
\hline Yakumo Ainu & 6.75 & 14.44 & 7.50 & & & & & & & & \\
\hline Korea & 9.64 & 2.95 & 10.49 & 25.11 & & & & & & & \\
\hline Fushun & 11.60 & 4.35 & 7.71 & 20.91 & 5.77 & & & & & & \\
\hline Hainan & 5.13 & 1.91 & 7.33 & 17.31 & 2.42 & 5.39 & & & & & \\
\hline Fukien & 11.89 & 8.08 & 12.53 & 26.58 & 10.66 & 9.70 & 7.45 & & & & \\
\hline Seil Peipo & 9.82 & 6.07 & 6.80 & 20.83 & 8.45 & 10.62 & 7.55 & 8.93 & & & \\
\hline Atayal & 5.49 & 10.02 & 9.07 & 15. 18 & 14. 29 & 16.43 & 7.23 & 11.09 & 13.15 & & \\
\hline Tagalog & 6.51 & 3.29 & 9.90 & 15.47 & 7.49 & 10.64 & 3.93 & 11.65 & 10.13 & 8.63 & \\
\hline Dayak & 5.22 & 4. 43 & 7.03 & 12.38 & 8.27 & 8.64 & 3.20 & 9.59 & 11.62 & 6.54 & 2.83 \\
\hline
\end{tabular}

are as follows;

Western Japan, Eastern Japan, Ryukyu .......below 5.23

Korea, Fushun, Hainan, Western

Japan -.....below 5.77

Hainan, Western Japan, Ryukyu,

Dayak, Tagalog ….below 6.51

Ryukyu, Dayak, Atayal …...below 6.54

Ryukyu, Yakumo Ainu ….......... 6.74

Western Japan, Eastern Japan,

Seil Peipo ......below 6.80

To Fukien, which has D-squares above 7.0 for all other populations, the nearest population is Hainan (7.45) and the farthest one Yakumo Ainu (26.58). Dsquares of Yakumo Ainu are above 12.0 for most of the populations under comparison, and are quite high for ChineseKorean group (above 17.0), but relatively low for Ryukyu (6.75) and Eastern Japan (7.50). It seems reasonable that the population closest to Ryukyu is Western Japan (4.53) and next one Eastern Japan (4.56) and that D-squares between Ryukyu and southern people, that is, Hainan (5.13), Dayak (5.22), Atayal (5.49), are not very high. Moreover, it should be noticed that the population closest to Yakumo Ainu is Ryukyu, followed by Eastern Japan.

It may be concluded that the Ryukyu Islanders are craniometrically one of the local groups of Japanese population and come close to some of the southern populations and to Yakumo Ainu, while most of the Chinese-Korean populations and Seil Peipo in Formosa are different from the Ryukyu people. These results accord well with IKEDA's conclusion that the Ryukyu people are different from the populations in the northern part of the Asian Continent and close to the southern people and that some of the cranial traits peculiar to the Ryukyu crania are found in the Ainu crania in more exaggerated form. A close genetic affinity between the Ryukyu Islanders and the Ainu was suggested by BAELZ ('11) and ADACHI ('37), but Suda ('50), Kanaseki ('55) and other many authors regard the Ryukyu Islanders as a local group of the Japanese population. Recently, however, HANIHARA 
et al. ('74) pointed out that the affinity of dental characteristics between the Ryukyu Islanders and the Ainu is closer than that between the Honshu-Japanese and the Ainu. The same results were sustained serologically by NAKAJIMA et al. ('67) and Misawa \& Hayashida ('68).

4. Comparison among Ryukyu, Jomon, Yayoi and Kofun crania

MiyaKe ('40) stated that some physical traits of the Stone Age Japanese had remained in the people of the secluded regions such as the Ryukyu Islands, where practice of marriage within a limited area had prevailed, and that Ainu-like physical characteristics found in these regions might be taken as clear evidence for this. On the other hand, this analysis was ascertained that the population closest to Yakumo Ainu is Ryukyu and the one closest to Korea is Western Japan, where some populations from the Asian Continent might have immigrated in or after the Yayoi Age. In the light of these results and suggestions, it is necessary to compare the Ryukyu crania, and also the other modern Japanese, the Ainu and Korean crania, with the prehistoric and protohistoric crania in the Jomon, Yayoi and Kofun Age. Eight populations, including Ryukyu, Western and Eastern Japan, Yakumo Ainu, Korea, Yoshigo (the later Jomon Age), Doigahama (the early Yayoi Age) and Western Japan (Kofun Age) were used.

FUNCTIONS AND LOADINGS (Fig. 4, Table 7)

Function 1: On this function, which accounts for $57.3 \%$ of inter-group varia-

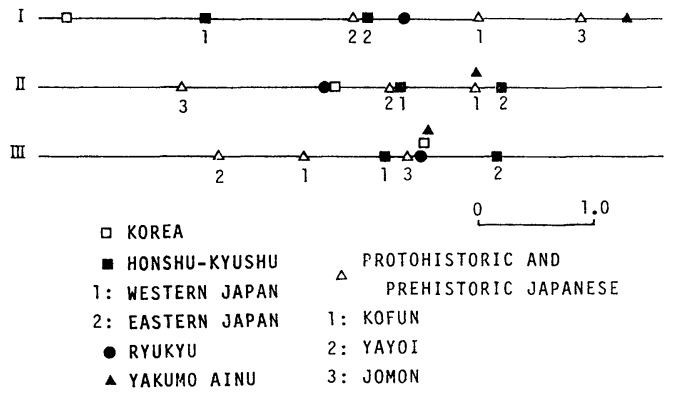

Fig. 4. Plot of the populations including the Jomon, Yayoi and Kofun Age populations on the first three functions.

Table 7. Discriminant loadings. Comparison among the populations including protohistoric and prehistoric populations.

\begin{tabular}{lrrr}
\hline \multicolumn{1}{c}{ Function } & 1 & 2 & 3 \\
Cumultive trace (\%) & 57.3 & 75.8 & 88.0 \\
\hline 1. Max cranial ln. & .327 & .086 & -.076 \\
2. Ba-na ln. & .197 & .017 & -.028 \\
3. Max. cranial br. & .057 & -.306 & -.111 \\
4. Min. frontal br. & .229 & -.147 & -.177 \\
5. Basion-bregma ht. & -.179 & -.261 & .360 \\
6. Horizontal circ. & .263 & .017 & -.263 \\
7. Transverse arc & -.069 & -.202 & .358 \\
8. Frontal arc & -.016 & .055 & .032 \\
9. Parietal arc & -.024 & -.210 & -.069 \\
10. Occipital arc & .013 & -.008 & .023 \\
11. Facial ln. & .349 & -.027 & -.072 \\
12. Bizygomatic br. & .065 & -.378 & -.326 \\
13. Upper facial ht. & -.377 & .295 & -.238 \\
14. Orbital br. & -.018 & .002 & -.034 \\
15. Orbital ht. & -.075 & .309 & .043 \\
16. Nasal br. & .058 & -.155 & -.293 \\
17. Nasal ht. & -.318 & .232 & -.233 \\
\hline
\end{tabular}

tion, Yakumo Ainu is in striking contrast to Korea. Kofun is close to Ainu, to which Jomon is the population closest; Western Japan is close to Korea. The remaining three populations, Eastern Japan, Ryukyu and Yayoi, are somewhere in-between Korea and Ainu. Loadings in a size component of the cranial vault (maximum cranial length, horizontal cir- 
cumference, minimum frontal breadth, cranial base length, facial length, with the positive sign) and in a general height component (basion-bregma height, upper facial height and nasal height, with the negative sign) are significantly high.

Functions 2 and 3: About 30\% of intergroup variation is carried by these two functions. Jomon on function 2 and Yayoi on function 3 are distinguishable from the other populations. The nearest population to Jomon on function 2 is Ryukyu and that to Yayoi on function 3 is Kofun. Loadings are relatively high in a general size component (maximum cranial breadth, basion-bregma height. transverse arc, sagittal parietal arc, bizygomatic breadth, with the negative sign) and in a facial height component (upper facial height, orbital height and nasal height, with the positive sign) for function 2 , and in the measurements of the brain case (basionbregma height, transverse arc, with the positive sign, and horizontal circumference with the negative sign) and a facial size component (bizygomatic breadth, upper facial height, nasal height and breadth, with the negative sign) for function 3 .
D-SQUARES (Table 8)

All D-squares of Ryukyu fall within a narrow range between 4.50 (v.s. Kofun) and 6.75 (v.s. Yakumo Ainu), with the exception of 9.63 for Korea. Almost the same tendency is seen in the case of Yayoi, Kofun and Eastern Japan. These results accord fairly well with that on function 1. Western Japan and Korea on one hand, and Yakumo Ainu and Jomon on the other, show the same relationships to other populations respectively, though D-square of Western Japan for each population is lower than that of Korea.

The Ryukyu Islanders are equally close to all the populations under comparison, except for the Korean. HaniHara $e t$ al. ('74) suggested that the similarities between the Ryukyu Islanders and the Ainu were probably caused by the conservative trends in more or less isolated populations and that they still retained some generalized characteristics of the ancient populations in East Asia. If this is correct, similarities among the Ryukyu Islanders, Jomon Age people and the Ainu could be explained, but what interpretation can be made of the resemblances among the Ryukyu Islanders, the other modern Japanese,

Table 8. D-squares among the populations including the protohistoric and prehistoric populations.

\begin{tabular}{lrrrrrrr}
\hline & Korea & $\begin{array}{c}\text { West. } \\
\text { Japan }\end{array}$ & $\begin{array}{l}\text { East. } \\
\text { Japan }\end{array}$ & Ryukyu & $\begin{array}{l}\text { Yakumo } \\
\text { Ainu }\end{array}$ & Kofun & Yayoi \\
\hline West. Japan & 2.95 & & & & & & \\
East. Japan & 10.49 & 5.23 & & & & & \\
Ryukyu & 9.64 & 4.53 & 4.56 & & & & \\
Yakumo Ainu & 25.11 & 14.44 & 7.50 & 6.75 & & & \\
Kofun & 15.64 & 7.59 & 5.31 & 4.06 & 4.27 & & \\
Yayoi & 10.25 & 4.80 & 6.96 & 4.80 & 10.28 & 3.92 & \\
Jomon & 21.92 & 14.64 & 12.09 & 5.24 & 7.54 & 8.65 & 10.20 \\
\hline
\end{tabular}


the Yayoi and Kofun Age people? The question of whether the similarity between the Ryukyu and the Ainu depends on genetic or environmental factors needs further investigation.

Finally, we shall discuss a genealogical problem of the Japanese, though this deviates from the main subject of this paper. A close affinity between the Western Japanese and the Korean and that between the Jomon Age people and the Ainu, and also a marked diversity between the Korean and the Jomon-Ainu morphology, have been recognized by many authors and have supplied arguments for discussions on the origin of the Japanese. KoganeI (1890) and others, who regarded such an affinity or contrast as the product of hereditary changes, advocated a substitution theory, that the Jomon Age people, the aboriginal preAinu or Ainu, were replaced by the ancestors of the modern Japanese, the immigrants from the Asian Continent in the Kofun Age. On the other hand, Hasebe ('49) and SuzukI ('69) attached importance to microevolutional changes in the Japanese population and proposed a transformation theory, that the Jomon Age people are the direct ancestors of modern Japanese. Moreover, KiYono et al. ('49) and KANASEKI ('58) believe that the Jomon Age people, the aboriginal proto-Japanese, mixed with some Mongoloid races from the Asian Continent in the Yayoi and Kofun Age. Without advancing any interpretation, we can say that a close connection between the Western Japanese and the Korean and that between the
Jomon people and the Ainu are clarified in function 1 and D-squares of this analysis. The distribution pattern of the populations on function 1 , excluding the Yayoi people, however, can be explained by either a transformation theory or a metisation theory. Discussions regarding the interpretation of craniometrical affinities of the Ryukyu Islanders to the prehistoric and protohistoric people in Japan, with reference to the origin of the Japanese, should be made on more extensive data in the future.

\section{ACKNOWLEDGMENT}

We wish to extend our appreciation to Mr. S. Oyama, Mr. C. Kishaba, Mr. S. Tawada, Dr. C. Nohara and Dr. T. Kano of Naha City, and Mr. K. Shimoji, Mr. K. OKamato of Hirara City, as well as many other persons in the Ryukyu Islands, and Mr. T. Mouri, the Laboratory of Physical Anthropology, Kyoto University, for their sympathetic assistance to us in the carrying out of our field research. This study was made possible in part by a grant from the Ministry of Education, and statistical calculations were processed by the FACOM 230-60/75 computers of the Data Processing Center, Kyoto University.

\section{REFERENCES}

ADACHI, B., 1895: On a skull found from the cave in Yonaguni-Island, Ryukyu. (in Japanese) J. Anthrop. Soc. Tokyo, 10: 466-472.

- 1937: Das Ohrenschmals als Rassenmerkmal und der Rassengeruch ("Achselgeruch") nebst dem Rassenunterschied der Schweissdrüsen. Zeitschrift für Rassenkunde. 
6: 273-307.

AokI, T., 1959: Anthropological studies of Miyako Islanders, Ryukyu. (in Japanese) Kumamoto Igk Z., 33: 2511-2525.

ArAGAKI, S., 1968: Physical and anthropological studies on the inhabitants of the Southern district in Okinawa Island, Ryukyu. (in Japanese) Nagasaki Igk Z., 43: 679-702.

AsAI, M., 1942: Anthropologische Untersuchungen uber die Schädel der Formosaner vom Hoklo-Stamm. (in Japanese) Journal of the Medical Association of Taiwan 41: sup. 3, 1-80.

BAElz, E., 1911: Liukiu Insuler, die Aino und andere Kaukasierähnlich Rasse in Ostasiens. Kor-Bl. Anthrop. Ges., 42: 187-191.

Bonin, G, 1931: Beitrag zur Kraniologie von Ost-asien. Biometrika, 23: 54-113.

CHANG, C., 1949: Anthropologische Untersuchungen über die Schädel von Atayal in Formosa. (in Japanese) Bulletins of the Anatomical Department of the National Taiwan University, Formosa, 6: 59-154.

CorruCCINI, R.S., 1973: Size and shape in similarity coefficients based on metric characters. Am. J. Phys. Anthrop., 38: 743-745.

HANihARA, K., T. MASUda and T. TANAKA, 1974: Affinities of dental characteristics in the Okinawa Islanders. J. Anthrop. Soc. Nippon, $82: 75-82$.

Harada, T., 1954: Craniometrical Studies on the South-western Japanese populations. (in Japanese) Jinruigaku-Kenkyu, 1: 1-51.

Hasebe, K., 1951: The Ancestors of the Japanese. (in Japanese) Tokyo, Iwanami-Shoten.

HiraI, T., 1927: Anthropologische Untersuchungen uber das Skelett der Sachalin-Aino I Teil. Der Schädel. (in Japanese) J. Anthrop. Soc. Tokyo, 42: supl.1-182.

HsÜ, H., 1948: Anthropologische Untersuchungen uber die Schädel der Riukiu-Insulaner. (in Japanese) Bulletins of the Anatomical Department of the National Taiwan University, Formosa, 2: 227-330.

HuAnG, S., 1948: Anthropologische Untersuchungen uber die Schädel von HainanChinesen. (in Japanese) Bulletins of the Anatomical Department of the National
Taiwan University, Formosa, 3: 123-210.

IKEDA, J., 1974: Craniometry of Miyako Islanders, the Ryukyus. (in Japanese) J. Anthrop. Soc. Nippon, 82: 150-160.

IW AI, S., 1959: Studies on Crania of the $\mathrm{Na}$ tives of Tokunoshima, Oshima-gun, Kagoshima Prefecture. (in Japanese) Med. J. Kagoshima Univ., 11: 295-335.

Jo, I., 1938: Anthropologische Untersuchungen uber die Skelettreste aus den protohistorischen Hügelgräbern in Japan I Teil. Der Schädel. (in Japanese) Anthropologischer Bericht, 1: 1-172.

KANASEKI, T., 1955: Ancient culture in Yaeyama Islands-An answer to Dr. M. Miyanaga's review-. (in Japanese) The Japanese Journal of Ethnology, 19: 107-141.

- 1958: People of Yayoi Age. (in Japanese) Medecine of Japan in 1959. Proceedings of the Fifteenth General Assembly of the Japan Medical Congress, 1: 167-174.

- 1963: Note on the skeletal material collected during the Ryukyu survey 1960. Asian Perspective, The Bulletin of the FarEastern Prehistory Association, 6: 139-144.

KANASEKI, T., M. NAGAI and H. SANO, 1960 : Craniological studies of the Yayoi period ancients, excavated at the Doigahama site, Yamaguchi Prefecture. (in Japanese) Jinruigaku-Kenkyu, 7 : sup. 1-36.

KIKUCHI, J., 1959: An anthropological study of the cranial bones of the Yoro Islanders, Oshima-gun, Kagoshima-prefecture, Japan. (in Japanese) Jinruigaku-Kenkyu, 6: 366-398.

KINTAKA, K., 1928: Anthropologicsche Untersuchungen über das Skelett der YoshikoSteinzeitmenschen. I Teil, Der Schädel. (in Japanese) J. Anthrop. Soc. Tokyo, 43: supl. 495-736.

, 1929: On a human bone from Unten, Liu-kiu. (in Japanese) J. Anthrop. Soc. Tokyo, 44: 399-427.

Kiyono, K., S. Sugiyama, S. Miyake and E. NAKAYAMA, 1949: Study on the Japanese

Race based on the Ancient Skeletons. (in Japanese) Tokyo, Iwanami-Shoten.

KOGANEI, Y., 1890: On human bones found 
among shell-heaps in Japan. (in Japanese) J. Anthrop. Soc. Tokyo, 6: 41-46.

Matsumoto, S., 1956: Anthropological studies of modern Japanese skulls in central Kyushu. (in Japanese) Kumamoto Igk Z., 30; 834-879. MisawA, S. and Y. HAyAshida, 1968: On the blood groups among the Ainu in Shizunai, Hokkaido. Proc. Japan Acad., 44: 83-88.

MIYAKE, S., 1940: Anthropometry of Japanese. (in Japanese) Jinruigaku Koza, 19: 1-19.

Miyamoтo, H., 1924: Anthropologische Untersuchungen uber die Ostasiatischen Menschenrassen. Serie I. Lieferung 2. Anthropologische Untersuchungen über das Skelett der rezenten Japaner. I. Teil. Der Schädel. (in Japanese) J. Anthrop. Soc. Tokyo, 39: 307-451.

NAGAI, M. and H. SANO, 1966: On the human skeletal remains from Yonaguni Island, Ryukyu (Preliminary Report). (in Japanese) Proceeding of the Joint Meeting of the Anthrop. Soc. of Nippon and the Japanese Soc. of Ethnology 19th Session, 1964 at Kyoto ; 68-71.

NaIto, Y., 1973: Anthropological studies of the Nansei-islanders. (in Japanese) Jinruikagaku, 25: 163-194.

NAKAJIMA, H. et al., 1967: The distribution of several serological and biochemical traits in East Asia. II. The distribution of ABO, MN, S, Q, Lewis, Rh, Kell, Duffy and Kidd blood groups in Ryukyu. Jap. Jour. Human Genet., 12: 29-37.

NAKANO, T., 1958: An anthrnpological study on the skulls of Kikai-islanders of Amami Archipelago, Japan. (in Japanese) JinruigakuKenkyu, 5: 188-219.

OMORI, A., S. YASUdOME and M. TOMA, 1966 : Anthropometry of the Ishigaki and Miyako Islanders. (in Japanese) Joint Meeting of the Anthrop. Soc. of Nippon and the Japanese Soc. of Ethnology 20th Session at Sendai; 224-225.

OTsuki, Y., 1930: Anthropological studies of Japanese crania in Hokuriku District. (in Japanese) The Journal of Juzen Medical Society, 35: 81-97, 468-484, 606-621, 1585-1618, 1980-1998, 2575-2590.
OYADOMARI, G., 1968: Physical and anthropological studies on the inhabitants of the northern district in Okinawa Island, Ryukyu. (in Japanese) Nagasaki Igk Z., 43: 632-653.

OYAMA, H., 1956: Craniological studies on the Yoron Islanders, Oshima-gun, Kagoshimaprefecture, Japan. (in Japanese) JinruigakuKenkyu, 3: 396-434.

SAKIHARA, E., 1968: Physical and anthropological studies on the inhabitants of the middle district in Okinawa Island, Ryukyu. (in Japanese) Nagasaki Igk Z., 43: 654-678.

ShimA, G., 1933: Anthropological study of the Chinese skull obtained from the suburbs of Fushun, Manchuria. (in Japanese) J. Anthrop. Soc. Tokyo, 48:423-537.

, 1934: Further notes on the anthropological studies of the modern Korean (The skull). (in Japanese) J. Anthrop. Soc. Tokyo, 49: 245-267.

SuDA, A., 1950: The physical anthropology of the Ryukyuans. (in Japanese) Jap. J. Ethnol., 15: $23-30$.

SUzUKI, H., 1969: Microevolutional changes in the Japanese population from the prehistoric age to the present day. Jour. Fac. Sci. Univ. Tokyo, Sec, V, vol. III, part 4: 279-309.

TomizAw A, T., 1969: Physical and anthropological studies on the inhabitants of Tokunoshima Island in Amami Archipelago, Japan. (in Japanese) Nagasaki Igk Z., 44: 45-69.

Toy AmA, K., 1959: Somatological studies on the inhabitants of Kunigami, Okinawa island, Riukiu. (in Japanese) Jinruigaku-Kenkyu, 6: 1064-1084.

WAtanabe, S., 1938: Kraniologie der Yakumo-Ainu. Sapporo.

YAMASAKI, M., M. YAMASAKI, S. KANDA and K. KURISU, 1967: Craniometrical study of the Tohoku Japanese skulls. (in Japanese) J. Anthrop. Soc. Nippon, 75: 94-102.

YUAN, T., 1960: Anthropologische Untersuchungen uber die Schädel von Sail-Peipo auf der Insel Formosa. (in Japanese) JinruigakuKenkyu, $7:$ 243-290.

(Received August 13, 1976) 
Appendix. Cranial measurements and indices

\begin{tabular}{|c|c|c|c|c|c|c|}
\hline & \multicolumn{3}{|c|}{ Iriomote } & \multicolumn{3}{|c|}{ Miyako (Karimata) } \\
\hline & $\mathrm{n}$ & Mean & S.D. & $\mathrm{n}$ & Mean & S.D. \\
\hline 1 Maximum cranial length & 35 & 180.84 & 6.24 & 16 & 182.56 & 6.23 \\
\hline 3 Glabella-lambda length & 36 & 176.28 & 6.25 & 16 & 178.44 & 6.49 \\
\hline 5 Basion-nasion length & 31 & 102.05 & 3.77 & 11 & 102.05 & 5. 09 \\
\hline 8 Maximum cranial breadth & 35 & 139.53 & 4. 68 & 16 & 142.31 & 9.10 \\
\hline 9 Minimum frontal breadth & 35 & 93.41 & 4.87 & 16 & 91.56 & 4.71 \\
\hline 10 Maximum frontal breadth & 36 & 112.97 & 3. 96 & 16 & 113.50 & 4.95 \\
\hline 11 Biauricular breadth & 35 & 125.24 & 4. 67 & 16 & 125. 31 & 6.07 \\
\hline 12 Maximum occipital breadth & 35 & 109.04 & 3. 66 & 16 & 108. 31 & 4.25 \\
\hline 13 Bimastoid breadth & 33 & 107.50 & 3. 80 & 13 & 105.96 & 5. 08 \\
\hline 17 Basion-bregma height & 31 & 137.53 & 4.95 & 11 & 138.05 & 3.91 \\
\hline 20 Auricular height & 36 & 117.44 & 5.03 & 15 & 119.90 & 3. 40 \\
\hline 23 Horizontal circumference & 35 & 514.41 & 12.87 & 16 & 519.13 & 17. 34 \\
\hline 24 Transverse arc & 35 & 313.70 & 11.25 & 16 & 318.06 & 9.82 \\
\hline 25 Sagittal arc & 30 & 371.33 & 13. 49 & 13 & 376.27 & 12.99 \\
\hline 26 Frontal arc & 36 & 125.11 & 7.06 & 16 & 128.69 & 6.12 \\
\hline 27 Parietal arc & 36 & 128.53 & 8.83 & 16 & 130.19 & 6.35 \\
\hline 28 Occipital arc & 30 & 117.03 & 6.43 & 13 & 119.88 & 5.71 \\
\hline 29 Frontal chord & 36 & 110.44 & 5.46 & 15 & 113.23 & 4.91 \\
\hline 30 Parietal chord & 36 & 114.86 & 7.03 & 15 & 115.57 & 4.20 \\
\hline 31 Occipital chord & 30 & 98.80 & 3.98 & 13 & 101.65 & 4. 30 \\
\hline 40 Facial length & 24 & 101.58 & 3.97 & 10 & 103.20 & 2.91 \\
\hline 43 Upper facial breadth & 35 & 104.93 & 3. 66 & 15 & 103.37 & 4.05 \\
\hline 44 Biorbital breadth & 33 & 98.35 & 3. 17 & 13 & 99.04 & 6.10 \\
\hline 45 Bizygomatic breadth & 32 & 135.72 & 4.86 & 11 & 137.32 & 5. 34 \\
\hline 46 Middle facial breadth & 32 & 100.31 & 3.07 & 13 & 101.58 & 4. 21 \\
\hline 48 Upper facial height & 29 & 67.05 & 3.84 & 15 & 65.77 & 5.90 \\
\hline 50 Interorbital breadth & 33 & 17.98 & 1.73 & 16 & 17.00 & 1.93 \\
\hline 51 Orbital breadth $(l)$ & 34 & 42.56 & 1. 50 & 16 & 42.44 & 1.84 \\
\hline 52 Orbital height $(l)$ & 34 & 32.56 & 1.50 & 16 & 33.25 & 2.27 \\
\hline 54 Nasal breadth & 32 & 26.09 & 1. 66 & 15 & 26.43 & 2.05 \\
\hline 55 Nasal height & 34 & 51.88 & 2.98 & 16 & 50.94 & 4.44 \\
\hline 60 A.lveolar length & 26 & 54.38 & 3. 39 & 7 & 56.07 & 2. 37 \\
\hline 61 Alveolar breadth & 24 & 64.29 & 3.09 & 8 & 63.50 & 2. 39 \\
\hline 62 Palatal length & 27 & 45.76 & 3. 11 & 9 & 45. 17 & 2.55 \\
\hline 63 Palatal breadth & 18 & 40.33 & 2.87 & & & \\
\hline 8/ 1 Cranial I. & 35 & 77.17 & 3.57 & 15 & 76.93 & 2.77 \\
\hline 17/ 1 Height-length $\mathrm{I}$. & 31 & 75.97 & 2.64 & 11 & 76.54 & 1.13 \\
\hline 17/ 8 Heigh-breadth I. & 31 & 98.51 & 4. 41 & 11 & 97.38 & 5.77 \\
\hline 20/ 1 Auricular height-length I. & 35 & 64.85 & 2.82 & 15 & 65.93 & 1.43 \\
\hline 20/ 8 Auricular height-breadth I. & 35 & 84. 10 & 3. 12 & 14 & 85.94 & 2.66 \\
\hline 9/10 Transverse frontal I. & 35 & 82.62 & 3.20 & 16 & 80.61 & 2.88 \\
\hline 9/ 8 Transvers frontoparietal I. & 34 & 66.87 & 3. 05 & 15 & 65.22 & 2.45 \\
\hline 27/26 Sagittal frontoparietal I. & 35 & 103.66 & 6.58 & 16 & 101.25 & 4.24 \\
\hline $29 / 26$ Sagittal frontal I. & 36 & 88.28 & 1.62 & 15 & 88.24 & 1.45 \\
\hline $30 / 27$ Sagittal parietal I. & 35 & 89.54 & 1. 41 & 15 & 89.15 & 1.23 \\
\hline $31 / 28$ Sagittal occipital I. & 30 & 84.44 & 2.22 & 13 & 84.76 & 1.55 \\
\hline 48/45 Upper facial I. & 26 & 49.48 & 1.99 & 10 & 48.84 & 3.92 \\
\hline $52 / 51$ Orbital I. (l) & 34 & 76.33 & 4.65 & 16 & 78.08 & 4.09 \\
\hline $50 / 44$ Interorbital I. & 33 & 17.86 & 1.53 & 13 & 17.13 & 1.94 \\
\hline $54 / 55$ Nasal I. & 32 & 49.86 & 4. 40 & 15 & 51.30 & 3.98 \\
\hline 61/60 Alveolar I. & 23 & 117.67 & 6.60 & 7 & 113.30 & 6.75 \\
\hline 63/62 Palatal I. & 16 & 87.33 & 10.38 & & & \\
\hline 45/ 8 Craniofacial I. & 32 & 97.14 & 2.69 & 11 & 97.10 & 3. 16 \\
\hline 9/43 Frontobiorbital I. & 35 & 88.96 & 3.08 & 15 & 89.11 & 4. 27 \\
\hline $9 / 45$ Zygo-frontal I. & 31 & 68.69 & 2.95 & 11 & 68.01 & 2.70 \\
\hline
\end{tabular}


of the Ryukyu Islanders' skulls (males).

\begin{tabular}{|c|c|c|c|c|c|c|c|c|}
\hline \multicolumn{3}{|c|}{ Okinawa Honto } & \multicolumn{3}{|c|}{ Tokunoshima } & \multicolumn{3}{|c|}{ Kikai } \\
\hline $\mathrm{n}$ & Mean & S.D. & $\mathrm{n}$ & Mean & S.D. & $\mathrm{n}$ & Mean & $\overline{\text { S.D. }}$ \\
\hline 11 & 180.50 & 7.95 & 24 & 180.13 & 5.88 & 7 & 182.36 & 6.34 \\
\hline 11 & 177.14 & 7. 39 & 24 & 176.04 & 5.59 & 7 & 178.07 & 5.68 \\
\hline 10 & 100.60 & 3. 93 & 22 & 102.68 & 3. 54 & 5 & 101.90 & 2.51 \\
\hline 11 & 143. 32 & 4. 31 & 23 & 140.37 & 4.66 & 7 & 143.36 & 4.71 \\
\hline 11 & 92.50 & 5. 64 & 24 & 92.67 & 3. 87 & 7 & 96.36 & 2.67 \\
\hline 11 & 115.68 & 3. 76 & 24 & 115.67 & 3.73 & 7 & 118.50 & 4. 16 \\
\hline 11 & 125.32 & 5.93 & 23 & 125.63 & 4.57 & 7 & 127.50 & 5.42 \\
\hline 11 & 104.95 & 5. 32 & 24 & 107.21 & 4. 22 & 7 & 107.50 & 4.24 \\
\hline 11 & 102.50 & 7. 40 & 20 & 105.65 & 3. 36 & 7 & 105.93 & 2.99 \\
\hline 10 & 136.20 & 3. 56 & 22 & 136.32 & 4. 91 & 5 & 138.50 & 1.87 \\
\hline 11 & 115.95 & 3. 59 & 24 & 115.46 & 4. 40 & 7 & 117.07 & 3.55 \\
\hline 11 & 512.86 & 19.03 & 23 & 515.15 & 12.76 & 7 & 521.50 & 15.99 \\
\hline 11 & 317.50 & 7. 32 & 23 & 312.24 & 11.55 & 7 & 316.64 & 7.54 \\
\hline 11 & 371.86 & 13.92 & 21 & 368.26 & 13. 11 & 5 & 377.10 & 17.91 \\
\hline 11 & 127.05 & 5.77 & 24 & 126.71 & 4.99 & 7 & 125.50 & 6.35 \\
\hline 11 & 129. 32 & 6.85 & 24 & 127.17 & 9.04 & 7 & 125.93 & 4.08 \\
\hline 11 & 116.41 & 8.32 & 21 & 115.12 & 8.65 & 5 & 125.50 & 12.55 \\
\hline 11 & 110.50 & 4.31 & 24 & 111. 08 & 4. 04 & 7 & 111. 21 & 4. 82 \\
\hline 11 & 114.59 & 8.02 & 24 & 113.00 & 6.85 & 7 & 112.93 & 4.04 \\
\hline 11 & 97.50 & 6.02 & 21 & 97. 69 & 5.24 & 5 & 102.30 & 4.97 \\
\hline 8 & 101. 38 & 5.30 & 15 & 101. 37 & 4. 53 & 3 & 100.83 & 5. 86 \\
\hline 11 & 104. 95 & 4. 11 & 24 & 105. 33 & 3. 52 & 7 & 106. 50 & 2. 38 \\
\hline 11 & 98.14 & 3. 20 & 22 & 97.41 & 2. 31 & 6 & 99.00 & 3.08 \\
\hline 10 & 132.00 & 6.04 & 22 & 134. 91 & 6.57 & 7 & 137.50 & 6.03 \\
\hline 10 & 101.70 & 4.73 & 22 & 102.82 & 4. 87 & 6 & 103.00 & 4.14 \\
\hline 8 & 66.13 & 4. 57 & 17 & 67.44 & 4.94 & 5 & 70.50 & 8.46 \\
\hline 11 & 18. 32 & 2. 60 & 24 & 18.29 & 1.79 & 7 & 18. 64 & 1.86 \\
\hline 11 & 42.32 & 1. 54 & 24 & 41.83 & 1.58 & 7 & 42.36 & 0.69 \\
\hline 10 & 32.90 & 1.78 & 24 & 33.25 & 1.80 & 7 & 34. 21 & 0.95 \\
\hline 10 & 26.80 & 1.77 & 23 & 26.20 & 1.58 & 7 & 26.79 & 3.20 \\
\hline 10 & 48.80 & 3. 27 & 24 & 51.75 & 3. 07 & 7 & 52. 36 & 4. 06 \\
\hline 7 & 52.36 & 3. 08 & 14 & 53.50 & 3. 31 & 3 & 54.50 & 1.00 \\
\hline 7 & 61.93 & 3. 36 & 16 & 64.81 & 2.96 & 3 & 66.50 & 1.73 \\
\hline 9 & 43. 83 & 2.29 & 19 & 45.18 & 1.73 & 5 & 44.90 & 4.51 \\
\hline 4 & 41.75 & 0.96 & 11 & 40.41 & 1.22 & 3 & 41.83 & 0.58 \\
\hline 11 & 79.43 & 2. 97 & 23 & 78. 01 & 3.70 & 7 & 78. 62 & 3. 37 \\
\hline 10 & 76.03 & 2. 22 & 22 & 75.78 & 3. 22 & 5 & 75.74 & 2.46 \\
\hline 10 & 95.55 & 3. 35 & 21 & 97.21 & 2.82 & 5 & 96.44 & 2. 91 \\
\hline 11 & 64.20 & 2. 02 & 24 & 64.02 & 2.28 & 7 & 64.16 & 2.74 \\
\hline 11 & 80.88 & 2.78 & 23 & 82.31 & 3. 69 & 7 & 81.67 & 3. 47 \\
\hline 11 & 79.87 & 4. 17 & 24 & 80.05 & 2. 89 & 7 & 81.29 & 2.53 \\
\hline 11 & 64. 39 & 2. 88 & 23 & 65.92 & 2. 31 & 7 & 67.13 & 1.89 \\
\hline 11 & 101.89 & 5.45 & 24 & 100.38 & 6.29 & 7 & 100.49 & 4. 46 \\
\hline 11 & 86.97 & 2. 17 & 24 & 87.64 & 1. 39 & 7 & 88.61 & 1.66 \\
\hline 11 & 88.54 & 3. 31 & 24 & 88.90 & 1.93 & 7 & 89.63 & 1. 11 \\
\hline 11 & 83.76 & 2. 45 & 21 & 84.96 & 3. 14 & 5 & 81.79 & 4.53 \\
\hline 8 & 50.08 & 1.93 & 15 & 50.06 & 4.72 & 5 & 50.10 & 4. 35 \\
\hline 10 & 77.53 & 3. 36 & 24 & 79.24 & 3. 25 & 7 & 80.56 & 2. 42 \\
\hline 11 & 18. 22 & 2. 31 & 22 & 18. 10 & 1.61 & 6 & 18. 26 & 1.73 \\
\hline 10 & 54.55 & 3. 44 & 23 & 50.42 & 4.68 & 7 & 50.79 & 5.86 \\
\hline 7 & 118.51 & 2. 61 & 12 & 121.46 & 7. 16 & 2 & 122.00 & \\
\hline 4 & 92.71 & 0.95 & 11 & 88.78 & 3. 39 & 3 & 92.41 & 8.74 \\
\hline 10 & 92.54 & 3. 45 & 20 & 97.47 & 3. 12 & 7 & 95.90 & 2.54 \\
\hline 11 & 88.04 & 3. 04 & 24 & 87.93 & 2.70 & 7 & 90.45 & 2.58 \\
\hline 10 & 69.17 & 2. 93 & 21 & 67.63 & 2.63 & 7 & 70.02 & 1.69 \\
\hline
\end{tabular}


頭骨計測值の多変量解析からみた現代琉球人（男性）

\section{多賀谷 昭 - 池田 次郎 \\ 京都大学自然人類学研究室}

見代琉球人男性頭骨の 17 計測值について, 沖縄地方と奄美地方を比較した結果, 両地方間に明瞭な差がみら れ, 本州, 九州の 6 地方型とての両地方の分析では, 琉球人が日本人の地方型の一つであることが明らかとな った。次いで琉球, 西日本, 東日本を朝鮮, 中国, 台湾, インドネシアの諸種族および八雲アイヌと比較した 結果, 南方のいくつかの種族が本州, 九州に次いで琉球に近いとと, 比較集団中, アイヌにもっとも近いのが 琉球であるととが示された。最後に, 縄文, 弥生, 古墳人骨との比較では, 琉球はてれらおよび現代日本人, アイヌに同程度に近く, 朝鮮人とは比較的遠いという結果がえられた。 